\title{
The Ceiling Strategy as Policy: Limiting Bureaucratic Expansion and Democratization*
}

\author{
Hyemin Choi** and Jisu Jeong***
}

\begin{abstract}
It is commonly recognized that the transition to democracy in Korea was associated with economic progress. However, not many scholars have given attention to the role of bureaucracy during the process of democratization, due to the fact that bureaucracy is usually thought of as belonging to politics, not democracy. As a refutation of this general view, first, this paper argues that bureaucracy has been an important contributor to political modernization. Since the post-1945 period, the 'ceiling' strategy, which limits the total number of civil servants, was introduced into the personnel management method and system of checks and balances to limit undue political influence over staffing and to control bureaucratic expansion. Second, through this strategy as policy, the bureaucracy legitimately tried to avoid undemocratic political power by the standardized process and allow the coordination. The ceiling policy is originally the product of historical context during colonial and authoritarian period, but the bureaucracy utilizes it as the instrument to reduce corruption. The contribution of this paper is provoking the new insights about democratization from bureaucrat's perspective which is rarely highlighted.
\end{abstract}

Keywords: Ceiling Law, Bureaucratic Expansion, Democratization, Personnel Management

* This research is supported by National Research Foundation of Korea (NRF-2014S1A3A 2044898).

**Hyemin (Hemin) Choi is a PhD student in the Graduate School of Public Administration at Seoul National University, Korea. E-mail: herahemin@snu.ac.kr, Co-first author and Corresponding author.

*** Jisu Jeong is Senior Researcher at Korea Institute for Defense Analyses, Seoul, Korea. E-mail: rationeque@gmail.com, Co-first author.

Manuscript received December 27, 2016; out for review January 5, 2017; review completed February 23, 2017; accepted February 24, 2017.

The Korean Journal of Policy Studies, Vol. 32, No. 1 (2017), pp. 175-198.

(C) 2017 by the GSPA, Seoul National University 


\section{INTRODUCTION}

The total number of national civil servants is expected to hit a record of more than 1 million this year in Korea. ${ }^{1}$ The number is surprisingly more than double if the calculation includes quasi public sector employees who are partially paid through government subsidy. These numbers are almost $6.5 \%$ of the nation's total working population. Every year, the central and local government hires about 40,000 new employees, which is almost same as the combined number of top four chaebol companies recruited. Government is an active employer and recruiter that is as significant as the private sector in the job market. Public sector jobs are often preferred due to the job security, social security provisions, and welfare. Despite the low payment, there is a prevalent perception that a career in civil service provides a good quality job with stable working conditions because of the continuous demand for civil services.

Strong government implies not only the driver of economic development, but also the group of elite bureaucracy. Nevertheless, when GDP increases, government is praised, but ironically, when number of bureaucrats increase, government is blamed. We have stereotyped perception that the economic development is positive and the bureaucracy is negative impact to our society. In fact, a negative perception of the bureaucracy is inevitable because civil servants are working in a political environment. The bureaucratic system is always politically vulnerable unless all civil servants have clear and unbiased political neutrality. Also, higher ranking civil servants and ministers frequently intervene in the recruitment and appointment of personnel to expand their power and create unnecessary positions. This is usually the root cause of the bureaucratic expansion that is common in both developed and developing countries. Parkinson (1957) summarized this phenomenon as Parkinson's Law, which states that bureaucratic expansion is not due to an increased amount of work but rather the result of creating unnecessary positions.

Therefore, the absolute number of public servants is easily manipulated as evidence of a dysfunctional bureaucracy. Since this number is a common way to measure efficiency, sometimes a large number suggests the wrong assumption. A large number

1. Korean government and OECD have different standard of calculating public servants. In Korea, Ministry of Security and Public Administration annually announces official number of national civil servants. In 2016, official total number of national civil servants is $1,027,561$. This number includes public servants in central government $(61 \%$, not only general administrators but also teachers, police officers, post officers), local government (36\%), National Assembly, The Supreme court and Constitutional Court. https://org.moi. go.kr/org/external/dept/deptReportIntro.jsp. 
does not necessarily create a good image of the bureaucracy and the impression is that bureaucratic expansion will be inefficient, consume more taxes and generate more redtape. Furthermore, since the work of bureaucracy is mainly office work, the increased size of bureaucracy symbolizes increased personnel and budget. Therefore, the power of bureaucracy is all about the number-game.

\section{Why does the Number Matter in Developing Countries?}

Increased unnecessary positions within the bureaucracy have been a common dilemma that many developing countries are facing. Furthermore, these positions are easily used as the channel of corruption. In Ecuador, entry into the Civil Service is based on merit and competitive examinations. However, there is also occasional and temporary direct recruitment through civil contracts when a person is engaged by a public entity to provide a temporary service that cannot be covered by one of its permanent employees. They are not career staff but still have the same duties as public servants. Although they have a fixed-term contract, usually their term is renewed several times, which results in the reduction of career staff (OAS report). In Mongolia, the size of the bureaucracy fluctuated extensively after the parliamentary elections of 1996 and 2000, when the party in power changed. Almost 60 percent of all government staff, including civil service employees, were terminated and replaced. Turnover after the 2004 Parliamentary elections, when the same party remained in control, is estimated at between 30 to 40 percent of the staff. They are then replaced by staff chosen based on political patronage, including those who worked or contributed to the campaigns, regardless of whether or not they possess the capabilities or skills required by the jobs to which they are assigned. The bureaucracy is also used to provide jobs to members of Parliament who have lost an election (USAID report 2005). In Algeria, there was a remarkable expansion of the bureaucracy since the arrival to power of Bouteflika in 1999. As a result of an unmanaged bureaucracy, the government has announced a hiring freeze in most parts of the public sector, which already accounts for 60 percent of employment (Ford, 2016).

This paper views that the limiting of bureaucratic expansion can function as a system of controlling undemocratic power in an authoritarian context. Despite Korean bureaucracy evolved in the context of colonial and authoritarian era for long time, bureaucracy implemented their own strategy to democratize the administrative organization. In this paper, we conceptualize the democratization as the standardization of process by the rule of law. The law limits arbitrarily operated discretions. From that perspective, the process of developing a bureaucratic procedure to limit the size can be viewed as democratization in a developmental state. Through the examination of a 
Korean policy, 'The Ceiling Law,'2 which was initiated top down approach by bureaucracy, this paper argues that the bureaucracy in developing countries can take an active role to help democratization.

\section{BUREAUCRACY AND DEVELOPING COUNTRIES}

\section{The Role of Bureaucracy in the Developmental State}

Why does bureaucracy expand beyond a desirable size, especially in developing countries? In the case of Korea, the main reason behind bureaucratic expansion was economic development. The number of personnel in the bureaucracy has continuously increased due to the characteristics of the developmental state. Especially during the stage of 'condensed industrialization,' the role of government was broad and aggressive to catch up to industrialized countries. For example, from the mid-1960s to late 1980s, the Korean government set goals in five-year economic development plans, and the bureaucracy took on the role of a bank or enterprise and enjoyed the "late benefits" of industrialized countries in late industrialization (Gerschenkron, 1962). Elite civil servants continued to increase their power and capacity as the state actively maintained the state-led administrative structure until the 1997 economic crisis. Many studies agree that the government played an important role in the growth process of the Korean economy.

The developmental state is often conceptually positioned between a liberal open economy model and a centrally-planned model. However, the theory of the developmental state isn't about a dichotomous choice between capitalist and socialist systems. The developmental state is based on combinations of positive advantages of private business and the positive role of government (Bolesta, 2007). Often, the positive role of government was interpreted as the power of state intervention from an economic perspective to govern the market.

In that sense, Lariaux argued that 'the developmental state is an embodiment of a

2. Japan and United States also have similar law. In Japan, personnel were managed by the fixed total number law (1967). In United States, Federal Workforce Recruiting Act of 1994 has similar function. However, both of laws are different from Korean Ceiling Strategy because of two reasons. First, Japan and US use ceiling as the size reduction in order to achieve 'small government.' Second, Japan uses fixed total number law as reduction, pooling and redistribution of personnel. US use ceiling strategy in order to induce retirement. Both countries are using ceiling strategy as the perspective of reduction. On the other hand, the uniqueness about Korean Ceiling Strategy is oriented from the idea of prediction. 
normative or moral ambition to use the interventionist power of the state to guide investment in a way that promotes a certain solidaristic vision of national economy' (Lariaux in: Woo-Cumings 1999). Wade (1990) moved one step further and viewed the role of government in developmental state as entry-exit decision maker from an organizational perspective: "A pilot agency or economic general staff is one of the core features. The pilot agency decides which industries ought to exist and which industries are no longer needed in order to promote the industrial structure which enhances the nation's international competitiveness." Chang (1999) explained the role of government as not only regulating the economy, but also in relation with politics in a developmental state. However, the economic environment was continuously at the center of the developmental state discussion in a lot of literature, but there seems to be very little debate about the political environment necessary for a developmental state.

During the developmental stage, the Korean government was acting as both planner and implementer of the national economy. In this process, the role of bureaucrats was that of a mediator who scales down an ambiguous [ambitious?] vision to transform it into practice. The transferring method was through the characteristics of Weberian bureaucracy: the chain of command, procedure, hierarchical organization, expert, rule of law and documentation. These characteristics were based on scientific management and administrative principles in the combination of the government and the market. As Weber mentioned, bureaucracy is an inevitable consequence and result of modernity.

Korea between the 1960s and the 1980s probably provides the most 'extreme' case of the developmental state in organizational terms (Chang 1990). This period was a turbulent developmental stage with strong government-driven economic development planning by the Park government. In a relation to that, the goals were not limited to economic growth, but also to the development of human resources, national land reforms and a self-reliant national defense. The ambitious plans for policy reforms and socioeconomic development increased the workload of bureaucrats, and more government employees had to be hired as a result (Bello and Rosenfeld 1990, Boyer and Ahn 1991). However, unfortunately, additional public servants were hired who were not trained enough to achieve this goal [?]. In trying to upgrade the human resources of the bureaucracy, an alternative strategy was to create a new organization with fresh people. Powerful pilot agencies, such as the Economic Planning Board, the Ministry of Finance and the State-owned bank, were established during this economically turbulent stage. These types of government agencies required completely different skills and knowledge from public servants. Especially, the Economic Planning Board, which not only managed the (indicative) planning exercise but also controlled the budget and the foreign fund, needed diversified experts from across the spectrum including eco- 
nomics, law, international affairs, language and financing. Also, since the EPB coordinated the activities of the Ministry of Commerce and Industry, the banks and other state owned enterprises, highly educated individuals were desired from various disciplines. Young Ph.D. scholars who had studied abroad with Fulbright grants or academic professors were also [a high priority to be hired] in great demand.

Since the State Council Secretariat was abolished and reorganized as the Ministry of Government Administration in 1963, personnel administrative functions were still managed in the Personnel Management Bureau in the Ministry of Government Administration. However, due to the rapidly increasing number of public servants, MGA's personnel administrative workload increased drastically. Not only preparing and supporting cabinet meetings and promulgating new and revised legislation, ordinance and law, the ministry was in charge of public servant personnel management, managing all government organizational structure and quotas, improvement of general administrative work, managing public servants' insurance and retirement, merit system evaluations, training programs and managing government building facilities. The change in the political culture of citizen participation also increased the demand for public servants. After the democratization of the late 1980s, citizens believed that they were now in a genuine democracy and a democratic political culture emerged. They started asking actively about what they wanted from the government. Not only the quantity of demands, but also the specific and detailed nature of the demands was problematic. To satisfy their requests, government needed more human resources. Partly in response to this, the retirement age of street level bureaucrats was extended from 58 to 61 .

\section{Causes of Bureaucratic Expansion in Developing Countries}

\section{Underdeveloped private job market}

One simple answer for the reasons of bureaucratic expansion in developing countries is that becoming a civil servant is a decent job due to the underdeveloped private job market. Since the private market is not fully structured and developed, most businesses are rather small scale productions or family oriented businesses. Even though periods of economic growth have the largest impact on the reduction in the exit rates, the market size is still small and small firms' survival rate is also low. Therefore, the private sector cannot guarantee job security, particularly during periods of political uncertainty (Klapper et al, 2009). Often the available private sector jobs are blue-collar work in the industrial sector, especially manufacturing. In this context, working in government as a career civil servant is a privileged job in developing countries and 
considered white-collar work.

For example, to become a civil servant in Korea, there are two ways: entering by passing the strict qualifying exam or entering through a temporary position and surviving to become a career civil servant. The law of open-competition for public servants in the recruitment system (Articles 28, 1963) allows any talented individual to enter the bureaucracy. This merit-based system of recruitment carried out through open competition was not a new idea in Korea. Traditionally, Korea's public service system is rooted in its Confucian heritage such that public servants were typically either appointed by the royal court or recruited through highly competitive national exams. Regardless of social class, anyone who passed the national civil service exam, Gwageo, could become a public servant during the Joseon Dynasty Period (1392-1910).

Korea's economic and political situation was similar to that of many other developing countries, especially in the late 1970s to 80s. Although the career civil servant system had been continuously elaborated through law, it was not followed because of the under developed job market. During the 1960s and 1970s, large private companies expanded in parallel to the country's economic success. However, the number of large private companies was very small and available jobs were mostly in the manufacturing sector, which does not require a university degree. Furthermore, since the economy was still developing, the survival rate of companies was low, and job security in the private sector was low as well.

\section{Undemocratic political power}

Another problem was inherited culture of familialism. Scholars have characterized Korean administrative culture as hierarchical, authoritative, paternal, emotional, irrational and familial (Cho 1994; Paik 1982). Also, especially in the context of Confucian familism, hiring people through personal networks is still frequently considered a cultural norm in an agriculture-dominated society. Mainly, the root cause of the bureaucratic expansion was due to these appointed temporary workers recruited through the familial network.

The merit based recruitment system was officially considered as the only way to become a career civil servant by law. In a reality, however, only $20 \%$ of all civil servants were hired through the merit based open competition system (Cho, 1968). Behind the scenes, career civil servants who entered as appointed temporary workers made up the majority of the bureaucracy. The familial network can be easily manipulated to offer bribes for jobs and corruption. Career civil servants who entered as appointed temporary workers usually had a low quality of manpower and their concern was survival rather than performance, which degraded the quality of the overall 
bureaucracy. In this context, undemocratic political power means unequally treated and distributed opportunity using abuse of discretion.

The implication of this phenomenon is that the bureaucracy is a hindrance for democratization, rather than facilitator. However, even in Western countries, networking is a critical method for job recruitment, and hiring people through the network is encouraged. Therefore, the matter is not about the characteristics of temporary positions via the familial network, but the uncontrollable increase in the number of positions through undemocratic political power.

\section{CASE STUDY: THE CEILING POLICY ${ }^{3}$}

In order to control the expansion of temporal public servants and prevent the size fluctuation caused by undemocratic political power, Korean bureaucracy implemented their own policy called 'The ceiling law.' The Law of General Rules on organization and the ceiling of administrative agencies was enacted under The Government Organization Act in 1977. The purpose of the law is to set a rational standard of personnel ceiling management in order to manage administrative organization efficiently. The ultimate common goal of the ceiling was controlling and prediction for a stable bureaucracy.

\section{The Ceiling as Number Strategy: Table of Organization}

Korean bureaucracy has been managed based on headcounts from the beginning. The ceiling strategy originated from the concept of T.O which stands for Table of Organization. This is a table listing the number and duties of personnel and the major items of equipment authorized for a military unit. Originally, a table of organization and equipment (TOE or TO\&E) is a document published by the US Department of Defense which prescribes the organization, staffing, and equipment of units. TOE provides information on the mission and capabilities of a military unit as well as the unit's current status.

The history of the T.O -based personnel and organizational management system in Korea begins in the era of Korean War. After the Japanese colonial period ended, the

3. The ceiling policy only applies to administrative employees whom are working in central and local government. The ceiling policy is also called as 'Government manpower ceiling', 'Total personnel system' and 'Personnel quota system'. They convey similar meaning but translated differently by scholars. 
American Military Government created a new administrative structure in South Korea on the basis of a democratic system that affected the process of the formation of the Korean bureaucracy from 1945 until the establishment of the Republic of Korea on August 15th 1948. During the United States occupation period, the Military Governor General Hodge was ordered by the US government to impose an American Military Government on the framework of the Choseon Governor General and the first urgent task was to form some kind of administrative structure. In order to meet the day-byday problems of governing more than seventeen million people, the Military Governor needed a great number of competent civil officials trained for the purpose. For General Hodge, personnel management was driven by the US army system. By the end of 1945, the total personnel in groups and companies was only 541 officers and 1918 enlisted men whereas the number required by the Table of Organization for these organizations called for 638 officers and 2882 enlisted men (Lee).

An Office of the Military Governor document states that "there were approximately 175,000 positions to be filled both in government and public corporations" which shows that government officials are calculated as 'positions' and something needed to be 'filled' based on the structure of the 'table of organization.' The inherited ceiling concept during this period still endures in the system of bureaucracy. The position is still considered a unit of individual personnel. Furthermore, the 'seat' is the metaphor of the position which represents 'rank,' 'task,' 'seat' and 'job.'

\section{Within Central Government Organizations: System of Checks and Balances}

Since bureaucratic expansion in central government and local government occurs in different contexts, they share the same goal of a ceiling law, but their strategies are developed differently. Within the central government, the ceiling strategy was to create a strict administrative procedure in order to limit the increase of each ministry's total number of personnel. The Ministry of Government Administration was the control tower of this whole process. MGA (1948-1998) was first established with The Ministry of Interior Administration right after the official Republic of Korea Government was founded in 1948. Since then, the MGA has dealt with overall government administration, organizational management, personnel management, document system administration, office administration and government general affairs as overhead functions. In addition to that, the MGA also functioned as the central personnel administration for long time.

The MGA has been a crucial ministry within the central government. Although the MGA covered overall government administration with a broad spectrum of work, since it was considered as general administrative work, the ministry was constantly 
exposed to decomposition or abolition. However in 1963, the MGA was re-established with a new mission to create a stable working environment for civil servants, as evidenced by the following quote from then MGA minister Lee:

"The three main pillars of the state are the military, civil servants and corporations. The president requested that the government should create the stable environment for civil servants so that they can work devotedly even if the regime changes" (Lee, Seok Jae 13th MGA minister)

Since Minister Lee had a military background and a close relationship with President Park, he could exercise strong leadership for administration reform without political intervention. Major achievements were the revision of the existing public service law with more detailed requirements and more specifically described procedures. As a result, laws in relation to the recruitment system, remuneration policy, the incentive system, and welfare and pension were restructured. The revision included centralizing recruitment and selection, improving examinations, installing a performance rating system, adapting a new training system, improving pay administration, and installing a position classification system (Cheng, Haggard and Kang 1998).

In particular, MGA tried to restructure the foundation of the personnel system including the law of open-competition for the public servant recruitment system (Articles 28, 1963) and the career civil servant system. Although the career civil service system had been continuously reformed through the law to protect it from undemocratic political power, the minister's centralized personnel decision power was still used to hire individuals to unofficial positions. Therefore, the frequent replacement of ministers eventually resulted in the frequent replacement of bureaucrats. Consequently, every time a new minister was appointed, the size of the bureaucracy expanded.

Due to the merit based recruitment system, central government regularly filled with competent personnel. Therefore, within the central government bureaucracy, the more problem was not about total personnel, but balanced allocation of personnel among ministries. If one ministry has more personnel than other ministries, that may cause an unbalanced power distribution. Also, since each ministry has overlapping functions, a redundant work force can emerge. Therefore, the ceiling strategy for the central government was created based on a strict schedule of checks and balances.

The law precisely describes the procedures that each ministry has to follow in order to revise their staff ceiling number every year. This strict procedure forces each ministry to prepare the following year's specific projects and to plan in advance. Planning is not only for filling the gap of the currently needed workforce, but also for preparing needed workforce in the future. In order to estimate the needed seats, each ministry 
Figure 1. Central Government Organizations: Annual Ceiling Number Approval Process

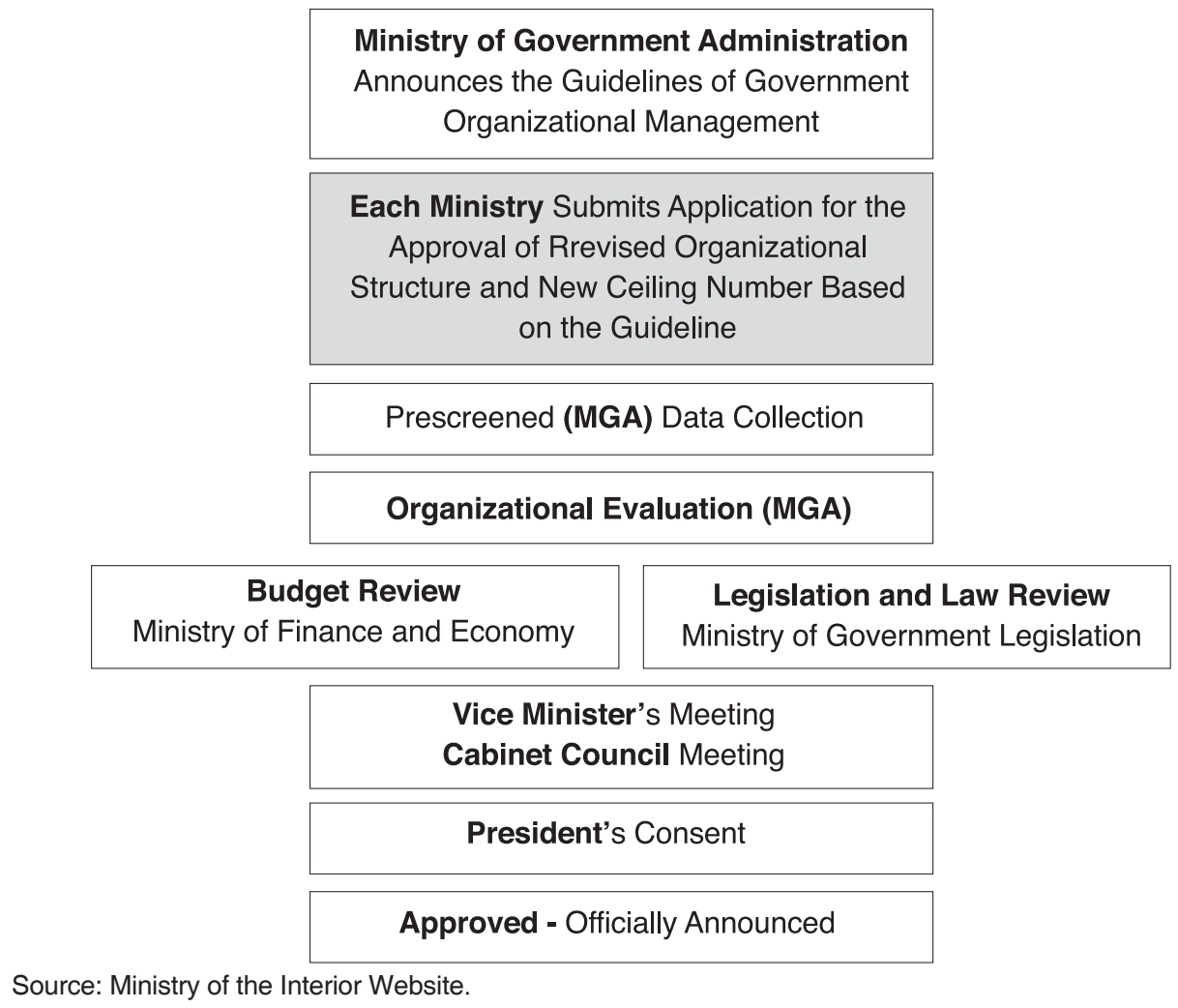

has to consider both the internal situation and the external environment. Internally, they need to decide where work should be focused and which projects will be outsourced. Project planning and scheduling is strongly related to personnel and not only full-time but also fixed-term public servants and the temporary workforce should be considered. To assign the right number of people, with the right attitude and skills, in the right place at the right time, defining a clear goal and mission is a necessity.

As shown in Figure 1, every year, each ministry applies a revision of organizational structure and a new ceiling number for approval. At this stage, each ministry has to submit a long-term strategy plan for their ministry that includes the reason for requesting a new ceiling number. Additional supporting documents can be requested by the MGA. Once the MGA accepts the application from each ministry, the managerial level first prescreens the applications and checks the requirements. Once each MGA manager confirms the requests, an official organizational evaluation is initiated. During this 
process, the organizational review and the ceiling number review are processed separately. The main purpose of the organizational review is to evaluate the function of the ministry. The ceiling number review is to evaluate the requested number of personnel based on the proposed organizational structure and long-term strategy. Once both reviews are completed, the next step is a budget review by the Ministry of Finance and Economy and a legislative law review by the Ministry of Government Legislation. Both are steps in the checks and balances system.

\section{Central-Local Government: Rational Scientific Model}

A large number of bureaucrats in central government belonged to an elite who had been selected through the merit based system. On the other hand, in the 1970s, bureaucrats in local governments were less competitive and highly influential through undemocratic political power, so that the central government had to limit local governments' bureaucratic expansion. Local government had strong bond with community and local interest group. Their power was uncontrollable and inhibits the equal opportunity. In order to limit undemocratic discretions in local government, the central government used the ceiling strategy to provide a legitimate total number of public servants. Those tasks were managed by the Ministry of Interior Administration (MIA, 1948-1998).

MIA was established in 1948 with the MGA. Compared to the MGA, which was managing the central government, the MIA was founded to manage home affairs including mainly administrative management for local and public security such as civil defense training, disaster management and fire services. The enacted local autonomy law (1949) aimed to strengthen local government, but it took 20 years to initiate the local elections of the mayors of Seoul and Pusan, provincial governors, and local councils. Even that attempt was placed on hold under the system of military rule during 1961 - 1970. During this period, major cities were under the direct control of the central government in that provincial administrations and mayors directly reported to the Ministry of Interior Administration. Even most personnel were appointed by the political power. The mayor of Seoul was appointed by the president and usually was regarded as his close confidant. Heads of other administrative divisions were recommended by the minister of Interior Administration for presidential approval. Mayors of ordinary cities and managerial levels of local career civil servants were recommended by the provincial governor for appointment by the president. Therefore, until 1988, personnel management was based on the individual approval system.

The MIA adopted the ceiling system which was characterized by a slightly different approach from the MGA's ceiling strategy. MIA's ceiling strategy was not a proce- 
dure, but rather a rational scientific model with the aim to set the number. This ceiling number was driven by a simple regression to predict needed personnel for the future. Not only that, the ceiling number was a reasonable source of defense when local governments asked to hire more personnel. In terms of the local government, there was no ceiling for the local government until 1988 due to the inactive local autonomy system. Until then, the central government fully controlled local government, and every request had to be approved by the MIA.

Table 1. The Enacted History of Ceiling Law

\begin{tabular}{|c|c|c|}
\hline & $\begin{array}{l}\text { Ministry of Government } \\
\text { Administration (MGA) }\end{array}$ & Ministry of Interior Administration (MIA) \\
\hline Purpose & $\begin{array}{l}\text { Managing civil servants in central } \\
\text { government } \\
\text { Coordination between Ministries }\end{array}$ & $\begin{array}{l}\text { Managing civil servants in local } \\
\text { government } \\
\text { Coordination of Central-local government }\end{array}$ \\
\hline Method & System of checks and Balances & Rational Scientific Model \\
\hline \multirow[t]{2}{*}{ Enacted law } & The Approval Procedure (1977) & $\begin{array}{l}\text { Individual Approval System }(\sim 1988) \\
\text { The Standard Ceiling System }(1988-94) \\
\text { The Total Ceiling Management }(1994-96) \\
\text { The new standard Ceiling System } \\
(1997-98)\end{array}$ \\
\hline & \multicolumn{2}{|c|}{ Emerged as Ministry of Security and Public Administration (1998) } \\
\hline Enacted law & \multicolumn{2}{|c|}{ The new standard Ceiling System (2003-06), The fixed budget (2007-) } \\
\hline
\end{tabular}

\section{Independent Variables for the Ceiling Number}

In academia, efforts have been made to study the demand and the capacity of civil servants in Korean context starting with the article of Cho Suk-Choon (1976) "Predictive Model of Public Personnel and Manpower in 1982." The focus was prediction rather than reduction. Therefore, the concept of personnel is framed more as the capital of budget. In order to develop a regression model, the following variables had to be considered. 


\section{Population Variable}

The population can be simply defined as a group of people. However, the population age structure, which is the summary of the number of individuals of each age, depicts the actual characteristics of the population. It is useful in understanding and predicting future population growth, because each age group needs different services and administrative goals. For example, normally, older adults have different health care needs than younger age groups, and this will affect the demands placed on the health care system in the future. Therefore, the administrative demand can fluctuate based on the age structure. The central government and the local government must plan ahead to allocate human resources in order to supply rudimentary services for the survival and well-being of the people. The politically relevant strata of the population multiplies the demands for government services, and thus stimulates an increase in governmental capabilities, a broadening of the elite, increased political participation, and shifts in attention from the local level to the national level.

\section{Social System Variable}

The characteristics of economic and social systems can affect civil servants' workload. Esping-Andersen (1999) argues that the "East Asian Confucian states" such as China, Japan, Korea, Taiwan, Singapore and Hong Kong have an exceptionally low number of civil servants in comparison with Scandinavian countries such as Norway, Sweden, and Finland. The size of the public service sector relative to the population in Scandinavian countries is exceptionally large compared to other OECD countries. From the standpoint of the welfare system, the expansion of the role of the state for social welfare has been caused by the demand side triggering the expansion of the national service, the political aspect aiming at redistribution, and the institutional aspect of the government organization seeking expansion of the budget (Boix, 2000). These factors affect the expansion of government.

\section{Size of Economy Variable}

From an economic point of view, depending on whether the nation is market-oriented or government-centered, the required function and capacity of the bureaucracy varies. In the market economy, it is important to pursue minimum regulation and market autonomy. In this case, the role of public servants is to support legitimate competition with minimum manpower, and to maintain stable international relations through diplomatic security. On the other hand, in the case of the government-centered economy, the government acts as the regulatory entity such that an increase of regulation 
means the expansion of the public service. Regardless of the economic regime, as the economy grows, the number of taxpayers increases. Therefore, more local tax offices are needed, including the personnel in the finance department.

\section{Territorial Context (Area) Variable}

The size of countries is very diverse. China, one of the largest countries in the world, has $9,597,000 \mathrm{~km}^{2}$ of land; Tuvalu, the smallest country with a seat in the UN has an area of $26 \mathrm{~km}^{2}$. European countries have relatively small land areas, but a typical European citizen is governed by a series of up to six levels of governments, from a city council to the European Union. The spatial process of change which includes the level of urbanization across regions and countries also affects administrative territories and the size of the bureaucracy.

\section{Workload (Administrative demand) Variable}

Workload means the total amount of administrative work that the government should carry out. Conceptually, this is deducted [normalized?] as workload per worker. As such, administrative demand is the most direct determinant of public service demand, and even if it is difficult to quantify, the workload should be analyzed in any model. Administrative demand may change based on the following questions: Will the function of government expand? Can some administrative demand be outsourced to the private sector? Will there be additional investment? How will policy priorities will change? Will the population of beneficiaries increase? Therefore, in predicting civil servant demand, clear assumptions and quantitative plans or estimates of these problems must be made in advance. However, this is in fact a matter for the jurisdiction of high-ranking decision-makers. Therefore, it is hard to expect realistic long-term plans.

\section{Mode of administration Variable}

Mode of administration means the manpower dependency in administrative processes. It has the same meaning as the combined ratio of manpower and capital as the production factor (production mode). Even if the demand for public administration remains constant, if the dependency on manpower in the administrative process is high, the demand for civil servants will increase accordingly. The mode of administration should be reformed by the simplification of decision making processes and administrative procedures for performance improvement. Eventually, it will require a smaller number of civil servants. Therefore, to predict the optimum workload in the future, administrative reform should be made in advance. However, a change of 
administrative style takes a relatively long time to implement. Administrative reform (improvement) should be considered separately because it is a task to be pursued continuously. Rather, the problem of mechanization or computerization of administration should be examined as a competitive alternative to the problem of increasing or decreasing manpower.

\section{Quality of manpower}

The higher the qualifications of civil servants, the lower the quantitative demand for civil servants. In other words, quantity and quality of manpower are mutually substitutable attributes. To estimate the required number of civil servants, their qualitative level should be anticipated in advance. The quality of civil servants is closely related with the incentive system, training and education, which need investment. Manpower supply includes both quality and quantity, and the estimates of manpower should be classified based on the level of education and technical skills.

\section{Budget and Revenue (Finances)Variable}

In reality, the size increase of the civil service is implemented under a specific policy system, and the biggest constraint is often a financial reason to increase or decrease labor costs. Therefore, if the workload determines the aggregated total demand of civil servants, the decision type is determined by the financial conditions of the government.

\section{Analytical Method for Estimating Ceiling Number for Local Government}

In 1980s, based on consideration of independent variables, the standard ceiling was driven by a simple regression to predict the number needed in the future. This first ceiling strategy applied to local government in the late 1980s under the Local Government Act. The first model (1) of the standard ceiling only used the basic variable of population, land size of local area, number of local public organizations, and local revenue were considered as statistically significant variables.

$$
\text { Ceiling Number }=[1,086,245+(0.0015 \times \text { Local Population })] \times 1.05
$$

The regression model was periodically revised and the independent variables such as number of administrative districts, administrative workload (1990), number of administration districts (1991) were added for better prediction. However, criticisms were received that the independent variables in the simple regression model (1) treat 
each local government homogeneously. Therefore, in order to consider unique local characteristics, a more complex regression model was developed and introduced.

$$
E M P_{i j}=\beta_{0}+\beta_{1} X_{1 i j}+\beta_{2} X_{2 i j}+\beta_{3} X_{3 i j}+\beta_{4} X_{4 i j}+C_{i j}+T_{i j}
$$

Compared to the first model (1), the complex model (2) considered local factors and included various dummy variables to strengthen the model. $X_{1}$ is local population in each administrative area. $X_{2}$ represents number of public organizations in that area and $X_{3}$ is the land size of each administrative area. $X_{4}$ means settled revenue of general account. In the second revised model, dummy variables which considered local context are also reflected. The purpose of these models was not to provide the true number of public servants. Rather, it allowed both central and local governments to control themselves before hiring. Additionally, it provided legitimacy for the central government to control local government.

Table 2. Variables for Analytical Model

\begin{tabular}{|c|c|c|c|c|}
\hline Year & Model & $\begin{array}{l}\text { Dependent } \\
\text { variable }\end{array}$ & Independent variable & calculation \\
\hline 1989 & $\begin{array}{l}\text { Simple } \\
\text { Linear } \\
\text { Regression } \\
\text { (OLS) }\end{array}$ & $\begin{array}{l}\text { Ceiling } \\
\text { number }\end{array}$ & $\begin{array}{l}\text { - Population } \\
\text { - Area } \\
\text { - Number of public organizations } \\
\text { - Revenue }\end{array}$ & $\begin{array}{l}{[1,086,245+(0.0015} \\
\times \text { Local Population })] \\
\times 1.05\end{array}$ \\
\hline 1995 & $\begin{array}{l}\text { Least } \\
\text { Squares } \\
\text { Dummy } \\
\text { Variable } \\
\text { (LSDV) }\end{array}$ & $\begin{array}{l}\text { Ceiling } \\
\text { number }\end{array}$ & $\begin{array}{l}\text { - Population } \\
\text { - Area } \\
\text { - Number of public organizations } \\
\text { - Revenue } \\
\text { - Dummy variables* }\end{array}$ & $\begin{array}{l}\text { *differentiate } \\
\text { geographical and time } \\
\text { context }\end{array}$ \\
\hline 1999 & $\begin{array}{l}\text { Standardized } \\
\text { index } \\
\text { (SI) }\end{array}$ & $\begin{array}{l}\text { Ceiling } \\
\text { number }\end{array}$ & $\begin{array}{l}\text { - Population } \\
\text { - Area } \\
\text { - Number of public organizations } \\
\text { - Revenue } \\
\text { - Number of public servants } \\
\text { - Park area, recipient of } \\
\text { livelihood program }\end{array}$ & $\begin{array}{l}{[2067.8+(0.00022240 \times} \\
\text { Local Population })+ \\
(0.00060543 \times \\
\text { Revenue })]+ \text { ci(Fixed } \\
\text { dummy variables }+ \\
\text { ti(Fixed dummy } \\
\text { variables) }\end{array}$ \\
\hline
\end{tabular}




\section{Post-Ceiling Strategy}

Fixing the total personnel number in advance with a rigorous procedure stabilized the size of the bureaucracy, but there was also a dominant view that the government was limiting the ministry's autonomy and the resiliency of the organization too much. From a top-down perspective, planning fixed total personnel number in advance was efficient only at the ministry level. However, from a bottom-up perspective, projects were always exposed to unexpected challenges in the environment and faced the risk that a team would need more personnel or less personnel depending on the situation.

Because of these contingencies, the government introduced the Fixed Budget for Personnel Policy which allocates the total budget for personnel instead of imposing government-wide ceilings on staffing numbers. This aligned with the change from rank classification-based recruitment to job classification-based recruitment so that recruiting experts were allowed in each ministry to select and hire what they actually need. In the past, the personnel number was only planned by rank and even though organizations sometimes needed more entry level public servants, they had to hire middle level officials according to this plan. This mismatching problem could be resolved. Of course, a close monitoring of the procedure by the central personnel administration in the Ministry of Government Administration and Ministry of Finance still continues, but ministries could recruit, control and coordinate their personnel autonomously within their allocated budget.

In a broader sense, the Total Fluid-Personnel Policy (1997) was also introduced as the improved version of the Fixed Budget for Total Personnel so that personnel can be directly transferred or rearranged between ministries. However, there was a tendency that powerful ministries that receive a large amount of budget from the government would ask for more personnel from less powerful ministries. Personnel only flowed from the less powerful ministries to more powerful ministries so that it was difficult to maintain balance among them. The power relationship worsened because the powerful ministries became larger and acquired more human resources while the less powerful ministries became smaller (Im, 2003). In order to address these problems, the Fixed Total Occupations Policy (2013) was implemented. Since the Korean government's central model of controlling the total number was generally done at the ministry level, similar characteristics of teams or departments were created in each ministry. In order to avoid this redundancy, the government decided to manage not only a fixed number of public servants by ministry, but also the number of seats by position. The government asked each ministry to select $5 \%$ of their total positions as redundant positions, and they had to remove them by $1 \%$ every year. The main purpose was to reduce each ministry's size by managing redundant positions and reutilize them elsewhere. How- 
ever, which positions to eliminate is still an unsolved question.

\section{THE CEILING LAW AND DEMOCRATIZATION}

\section{Developing Procedure to Eliminate Undemocratic Power}

A further problem of undemocratic political power is unpredictability. For example, when the bureaucracy expands in the spoils system, an organization cannot predict what kind of positions will be filled and generated. Since the expenditure for existing positions in the bureaucracy is drawn from taxes, the wrong estimation eventually leads to a waste of public money.

Since the law operates within a predictable, consistent and limited framework, the value of the rule of law is to reduce arbitrary power and to ensure an orderly society ruled by a responsible and principled government (Raz, 1994). Democratic power means the rule of law and legitimized procedure. Weber also emphasized that the ideal type of bureaucracy is driven by principles such as "division of labor" and "rule of law". Weber argues that these principles are typical of modern bureaucracy such that it is the obligation of the bureaucrats to follow the procedures of carrying out their duties by law, and it is the duty of all to obey the orders of the public officers justified by them.

In that sense, the 'ceiling' policy was an instrument to control undemocratic power within the bureaucracy and external political influence. The term 'ceiling' symbolizes the maximum number. In personnel management, the ceiling implies a limit of the number of personnel assigned to an institution or department by law. The purpose of the law was to set the rational standard of personnel management through a scientific model and to forecast the needed total number of personnel every year.

An organization is a combination of functions and personnel that are organically inter-related to each other. However, the concept of the personnel ceiling states the optimum size of manpower that can achieve the organization's goals efficiently. Since the concept of manpower itself refers to human resources in terms of economy, the estimation of manpower demand is generally calculated as a specific output, that is, the quantitative scale of the labor force to achieve the production amount. Therefore, the optimum number of the personnel ceiling policy refers to the process of finding a reasonable number of personnel in accordance with the organization's workload and nature of work (Kim, 1980). 


\section{The Role of Bureaucracy and Democratization}

Bureaucracy and democracy are typically considered antithetical (Etzioni-Halevey, 1983). Usually, the terms bureaucracy and democracy are thought of as the contradiction between control and autonomy. Even though the logic for institutionalizing the bureaucratic form of organization was to ensure efficiency, equal treatment, good record keeping, and justification for every decision, the bureaucracy is often stereotyped as hierarchical, legalistic, and even authoritarian (Peters, 2010; Goodsell, 2004; $\mathrm{Du}$ Gay, 2000). Contrarily, democracy is conceptualized as an effective and reflective system that supports collective decisions by participants who express their preferences. The construction of democratic legitimacy is based on voting, interest aggregation, constitutional rights, or even self-government, but as Dryzek (2000) argues, the essence of democracy itself is now widely taken to be deliberation. Also, he argues that the level of democracy is dependent on the capacity for autonomy.

In that sense, democracy is closely related to the concept of participation. However, this paper defines democracy as a procedure which is driven by the rule of law. The law operates within a predictable, consistent and limited framework. Therefore, the value of the rule of law is to reduce arbitrary power (Raz, 1994). From that perspective, controlling the size of the bureaucracy is strongly related to democracy because it is about the process of removing undemocratic political influence and avoiding centralized power among a small number of civil servants. This also can be applied to Weber's ideal type of bureaucracy which is driven by principles such as "division of labor" and "rule of law." These principles are typical of modern bureaucracy and oblige bureaucrats to follow the procedures and carry out their duties consistent with law, and it is the duty of all to obey the orders of the public officers justified by them. In that sense, the ceiling policy, as a form of coercive law, was instrumental in controlling undemocratic phenomena in the bureaucracy during Korea's developmental stage.

\section{CONCLUSION}

Huntington (1965) argues that four sets of categories recur continuously in the definitions of political development. These are rationalization, nation building, democratization and participation. Among them, the democratization approach focuses on pluralism, competitiveness, and equalization of power. In that sense, the ceiling policy as law, political development in the bureaucracy is that of movement towards democracy. The ceiling policy was a procedure that allowed other ministries to participate in the 
ministry's future organizational structure, long term vision and personnel number. Also, the ceiling policy controlled bureaucratic expansion and enhanced the competitiveness of the bureaucracy, which was an essential aspect of political modernity (Coleman et al, 1960). Furthermore, the ceiling policy helped to distribute centralized power.

The ceiling management strategy reflects bureaucrat's will to avoid undemocratic political influence. The ceiling policy acted as a regulatory-type instrument. Within the authoritarian context, the hide-and-seek process was a constant process between political powers, which try to expand their power in the bureaucracy, and the rule of law, which focuses on the prevention of intervention. The ceiling policy was gradually elaborated through the law by bureaucrats themselves to strengthen the stability and predictability of the bureaucracy. The ceiling system has fostered democracy insofar as it has worked to control undemocratic phenomena in the bureaucracy.

Since the ceiling strategy has innate characteristics of top-down approach and evolved through authoritarian government, there is limit to link democratization. However, democracy needs to be constantly reinterpreted in various perspectives. In this sense, the contribution of this paper is to recognize the new debate on democratization in the Asian context especially in developing countries in a relation to the bureaucracy.

\section{Acknowledgement}

We are grateful to Tobin Im for providing us valuable insights. We also thank the journals' reviewers and various commentators for providing many valuable suggestions.

\section{REFERENCES}

Alesina, A. 2003. The size of countries: does it matter?. Journal of the European Economic Association, 1(2-3), 301-316.

Bello, W. F. 1990. Dragons in distress: Asia\&\#039;s miracle economies in crisis / Walden Bello and Stephanie Rosenfeld. San Francisco: San Francisco: Institute for Food and Development Policy, c1990.

Boix, C. 2000. Partisan governments, the international economy, and macroeconomic policies in advanced nations, 1960-93. World politics, 53(01), 38-73.

Bolesta, A. 2012. China as a post-socialist developmental state: explaining Chinese development trajectory. (Doctoral dissertation, The London School of Economics and Political Science (LSE)).

Boyer, W. W. 1991. Rural development in South Korea: a sociopolitical analysis / Wil- 
liam W. Boyer and Byong Man Ahn. Newark: London: Newark: University of Delaware Press; London: Associated University Presses, c1991.

Breton, A., \& Wintrobe, R. 1975. The Equilibrium Size of a Budget- maximizing Bureau: A Note on Niskanen's Theory of Bureaucracy. Journal of Political Economy, 83(1), 195-207.

Cho, Suk Choon. 1976. "Public Sector Manpower Forecasting Model and the Size of Manpower in 1982." Korean Journal of Public Administration, 14.1: 1001.

Cho, Suk Choon and Im, Tobin. Theory of Korean Public Administration, 2010. Print

Choi, B. S. 1988. Political and economic democratization and Its impact on the government-business relationship in Korea. Korean Journal of Policy Studies, 3 (1988): 30.

Choi, S. Y. 2012. Comparison of Civil Service Reform in the United States and Korea: Central Personnel Agencies and Senior Civil Service Systems. Korean Journal of Policy Studies, 27(3), 101-123.

Chung, J. Y., \& Kirkby, R. J. 2005. The political economy of development and environment in Korea (Vol. 73). Routledge.

Dryzek, J. S. 2002. Deliberative democracy and beyond: liberals, critics, contestations / John S. Dryzek. Oxford: Oxford : Oxford University Press, 2002.

Du Gay, P. 2000. In praise of bureaucracy: Weber, organization, ethics / Paul du Gay. London; Thousand Oaks, Calif.: London; Thousand Oaks, Calif.: SAGE, 2000.

Entwistle, T., Guarneros-Meza, V., Martin, S., \& Downe, J. 2016. REFRAMING GOVERNANCE: COMPETITION, FATALISM AND AUTONOMY IN CENTRALLOCAL RELATIONS. Public Administration, 94(4), 897-914. doi:10.1111/ padm. 12210

Evans, P., \& Rauch, J. E. 1999. Bureaucracy and Growth: A Cross-National Analysis of the Effects of; Weberian; State Structures on Economic Growth. American Sociological Review, 64(5), 748-765.

Esping-Andersen, G. 1999. Social foundations of postindustrial economies. Oxford University Press.

Etzioni-Halevy, Eva. Bureaucracy and Democracy: A Political Dilemma / by Eva Etzioni-Halevy. New York: London: Routledge; Taylor \& Francis [distributor], 2010. Print. Routledge Library Editions. Political Science; 7. Routledge.

Fiorina, M. P. 1977. The Case of the Vanishing Marginals: The Bureaucracy Did It. American Political Science Review, 71(1), 177-181.

Foweraker, J., \& Krznaric, R. 2002. The Uneven Performance of Third Wave Democracies: Electoral Politics and the Imperfect Rule of Law in Latin America. Latin American Politics and Society, 44(3), 29-60.

Gerschenkron, A. 1965. Economic backwardness in historical perspective: a book of 
essays / by Alexander Gerschenkron. Cambridge, Mass.: New York: Cambridge, Mass.: Harvard University Press; New York: Frederick A. Praeger, 1962, c1965.

Goodsell, C. T. 2004. The case for bureaucracy: a public administration polemic / Charles T. Goodsell (4th ed.. ed.). Washington, D.C.: Washington, D.C.: CQ Press, c2004.

Grinyer, P., \& Yasai-Ardekani, M. 1981. Strategy, structure, size and bureaucracy. Academy of Management Journal, 24(3), 471.

Holton, R. J. 1989. Max Weber on economy and society / Robert J. Holton and Bryan S. Turner. London; New York: London; New York: Routledge, 1989.

Huntington, S. P. 1965. Political Development and Political Decay. World Politics, 17(3), 386-430.

Im. T. 2003. Bureaucratic Power and The NPM Reforms in Korea. International Review of Public Administration, 89-102.

Im, T. 2014. Bureaucracy in Three Different Worlds: The Assumptions of Failed Public Sector Reforms in Korea. Public Organiz Rev, 14(4), 577-596.

Im, T. 2017. Public organizations in Asia / Tobin Im (1 Edition.. ed.): New York: Routledge, 2017.

Johnson, R. N. 1994. The Federal civil service system and the problem of bureaucracy: the economics and politics of institutional change / Ronald N. Johnson and Gary D. Libecap. Chicago; London: Chicago; London: University of Chicago Press, c1994.

Jeong, M \& Lee, J. 2016. Determining Factors of Employment Size in Local Governments. Journal of Korean Association for Local Government Studies, 28.4: 73-101

Kang, H \& Shin, W. 2004. Study on Local Government Ceiling Management. The Journal of Korean Policy Studies, 4.1: 37-55.

Kang, I. 2008. Comparative Study of Local Government Personnel in OECD countries. Korean Public Administration Review, 42.2:169-190.

Kim, S. 1980. Projection of the Aggregate Number of Civil Servants and Techniques for Estimating the numbers by Organization. Korean Journal of Public Administration, 18.1: 1112.

Kim, T. 2000. Comparisons of Public Sector Implement between Korea and Other OECD Countries" Korean Public Administration Review. 34.1: 117-135.

Lee, H. 1997. Local Autonomy and the Interior Department's Personnel Size Control. Korean Public Administration Review, 31.3: 89-105.

Lee, W. 1976. The Embryo of Korean Bureaucracy in 1945. Korean Quarterly, 7: 32-49.

Lee, E. 1995. A Comparative Study of Public Sector's Manpower Growth in Korea, 
Japan and USA" Korean Policy Studies Review, 4.1: 146

Lerner, D. 1960. The Politics of the Developing Areas. Gabriel Almond, James S. Coleman. American Journal of Sociology, 66(1), 96-97. doi: 10.1086/222829.

Maravall, J. M. a. 2003. Democracy and the Rule of Law [electronic resource]. In A. Przeworski (Ed.), Cambridge Studies in the Theory of Democracy: Cambridge: Cambridge University Press, 2003.

Meier, K. J. 2006. Bureaucracy in a democratic state: a governance perspective / Kenneth J. Meier, Laurence J.;Toole, Jr. Baltimore, Md.: Baltimore, Md.: Johns Hopkins University Press, c2006.

O'Donnell, G. 2004. "Why the rule of law matters." Journal of Democracy, 15.4: $32-46$.

Park, J \& Ham, J. 1995. A Study on Flexible Personnel Management: Focusing on the System of Total Government Workforce. KIPA Research, (13): 59-91

Parkinson, C. N. 1957. Pakinson's law: and other studies in administration / Cyril Northcote Parkinson. Boston: Boston: Houghton Mifflin, 1957.

Peters, B. 2010. Bureaucracy and Democracy. Public Organiz Rev, 10(3), 209-222.

Przeworski, A., \& Maravall, J. M. 2003. Democracy and the rule of law / edited by José María Maravall, Adam Przeworski. Cambridge, UK; New York, NY: Cambridge, UK; New York, NY: Cambridge University Press, 2003.

Raz, J. 1994. Ethics in the public domain: essays in the morality of law and politics / Joseph Raz. Oxford: New York: Oxford: Clarendon Press; New York: Oxford University Press, 1994.

Sen, A. K. 1999. Democracy as a Universal Value. Journal of Democracy, 10(3), 3-17.

Shin, W and Jeon, B. 2010 The Optimum Size Model for Local Government. Journal of Governmental Studies, 16.3: 143-183.

Ulrich, D., \& Barney, J. B. 1984. Perspectives in Organizations: Resource Dependence, Efficiency, and Population. The Academy of Management Review, 9(3), 471-481.

Wade, R. 1990. Governing the market: Economic theory and the role of government in East Asian industrialization. Princeton University Press.

Yong Duck, J., Yoon Ho, L., \& Deok Soo, K. 2011. Institutional Change and Continuity in Korea`s Central Agencies, 1948-2011 . Korean Journal of Policy Studies, 26(1), 21. 